\title{
NITROGEN METABOLISM OF THE ANTARCTIC BIVALVE Laternula elliptica (KING \& BRODERIP) AND ITS POTENTIAL USE AS BIOMARKER
}

\author{
Edson Rodrigues ${ }^{1 *}$, Gannabathula Sree Vani ${ }^{1} \&$ Helena Passeri Lavrado ${ }^{2 * *}$ \\ ${ }^{1}$ Laboratório de Bioquímica, Departamento de Biologia, Instituto Básico de Biociências, Universidade de Taubaté ( UNITAU). Av. Tiradentes, 500 - \\ Centro, Taubaté, São Paulo, Brasil. CEP: 12.030-010. \\ ${ }^{2}$ Departamento de Biologia Marinha - Universidade Federal do Rio de Janeiro - UFRJ - CCS - bloco A - sala 089 - Ilha do Fundão, Rio de Janeiro, \\ Brasil. CEP 21.949-900. \\ E-mails: *edsonrod@unitau.br,**hpasseri@biologia.ufrj.br
}

\begin{abstract}
The Antarctic marine environment is characterized by the extreme seasonality of the primary production in the water column and the low but stable temperatures. Both are considered the main factors in the adaptative evolution of Antarctic ectothermic organisms. Studies about physiological and biochemical processes of the cold-adapted species revealed the presence of antifreeze glycoproteins in the biological fluids and cold-adapted proteins. The low and stable temperatures have resulted in the appearence of enzymes with high catalytic efficiency and the absence of the thermal stress proteins in some Antarctic fishes. The austral winter promotes a seasonal food shortage, submitting the benthic ectotherms to long periods of starvation. This is particularly true for the organisms that depend on phytoplankton as their primary source of food. The Antarctic marine environment also presents areas of high copper concentrations on the sediment surface as well as cadmium in the water column. The bivalve Laternula elliptica, a circumpolar species, has been proposed as bioindicator for long term monitoring of heavy metals in the shallow waters of Antarctica due to its capacity to accumulate metals, especially cadmium and zinc. Like other Antarctic ectothermic organisms, L. elliptica changes its metabolism from aerobic to anaerobic as a function of temperature, being $6{ }^{\circ} \mathrm{C}$ critical and $9{ }^{\circ} \mathrm{C}$ lethal. This bivalve also shows a marked seasonality in its metabolism, with low oxygen consumption in winter as compared to summer. It is speculated that it enters into a dormancy state during the austral winter as it apparently retracts its siphons below the sediment surface. The apparent supression of the water pumping by the siphons during winter forces L. elliptica to mobilize its energy reserves, using the siphon proteins as its principal source of energy (ratio of oxygen consumption/excreted nitrogen $=3.0$ ). Even during summer, when the high food supply stimulates the bivalve growth, the metabolism is mainly protein based. (O:N ratio $=16)$. The excretory nitrogen metabolism of this bivalve is typically ammoniotelic, characterized by the excretion of almost $90 \%$ of nitrogen in the form of ammonia and $10 \%$ as urea. Probably, the urea excreted arises from the hydrolysis of the proteic aminoacid L-arginine by arginase in order to maintain the tissue levels of that aminoacid. In such case, the presence of this enzyme in the kidney tissues may be related to the physiological constraints caused by the retraction of the siphons and the requirements for the excretion of this nitrogen compound during the austral winter. Studies with the renal arginase of this bivalve showed a high metabolic tolerance to the metallic cations $\mathrm{Cu}, \mathrm{Zn}, \mathrm{Fe}$ and $\mathrm{Cd}$, when compared to the arginase behavior of other bivalves such as Dreissena polymorpha. The present work covers the life history of this bivalve, its potential use as a biomarker and its adaptations to the extreme marine environment conditions in Antarctica.
\end{abstract}

Key-words: Antarctica, benthos, Laternula elliptica, arginase, metabolism, ecophysiology, biomarkers, heavy metals.

\section{RESUMO}

METABOLISMO NITROGENADO DO BIVALVE ANTÁRTICO Laternula elliptica (KING \& BRODERIP) E O SEU USO POTENCIAL COMO BIOMARCADOR. O ambiente marinho Antártico é caracterizado pela extrema sazonalidade da produção primária na coluna d'água e por temperaturas baixas e estáveis. Esses dois fatores têm sido tratados como os principais responsáveis pela evolução adaptativa dos organismos ectotérmicos Antárticos. Os estudos sobre a presença de mecanismos bioquímicos e fisiológicos de 
adaptação às baixas temperaturas revelaram a existência de glicoproteínas anticongelantes nos fluídos biológicos e de proteínas adaptadas ao frio. Enzimas com elevada eficiência catalítica e a ausência de proteínas de estresse térmico em algumas espécies de peixes Antárticos revelam, em parte, algumas das adaptações experimentadas por esses organismos ao longo do processo evolutivo, sob a pressão seletiva das temperaturas baixas e estáveis. A sazonalidade alimentar, imposta pelo inverno austral, proporciona um longo período de restrição alimentar para os ectotérmicos bentônicos, especialmente para os filtradores de fitoplâncton, que dependem diretamente da produção primária como fonte de alimento. O ambiente marinho Antártico também apresenta regiões com elevada concentração de cobre na superfície do sedimento e de cádmio na coluna d'água. O bivalve infaunal Laternula elliptica apresenta distribuição circumpolar e tem sido postulado como um bioindicador para o monitoramento, a longo prazo, de metais pesados nas águas rasas do ambiente marinho Antártico, em função da sua capacidade de bioacumular alguns metais, em especial cádmio e zinco. Semelhante a outros organismos ectótermicos Antárticos, L. elliptica altera o seu perfil metabólico de aeróbio para anaeróbio, em função do aumento da temperatura ambiente, estabelecida em $6^{\circ} \mathrm{C}$, como crítica e a $9^{\circ} \mathrm{C}$, como letal. Esse bivalve também apresenta uma acentuada sazonalidade metabólica, marcada pelo baixo consumo de oxigênio, no inverno, em relação ao verão, o qual é acompanhado pela aparente retração do sifão para uma posição abaixo da linha do sedimento, levando a especulação sobre um possível estado de dormência ao longo do inverno austral. A aparente supressão do bombeamento de água pelos sifões, durante o inverno, leva L. elliptica a mobilizar as suas reservas energéticas e utilizar proteínas do sifão como o seu principal combustível energético (razão oxigênio consumido/nitrogênio excretado $=3,0$ ). Mesmo durante o verão, quando a oferta alimentar acelera o crescimento desse bivalve, o metabolismo da L. elliptica continua sendo principalmente protéico (razão O:N =16). O metabolismo nitrogenado excretório desse bivalve é tipicamente amoniotélico, caracterizado pela excreção de $90 \%$ do nitrogênio na forma de amônia e 10\% como uréia. Provavelmente, a uréia excretada é decorrente da hidrólise do aminoácido protéico L-arginina, como forma de manutenção dos níveis teciduais desse aminoácido, em reação catalisada pela arginase. Neste caso, a presença dessa enzima no tecido renal da L. elliptica pode estar relacionada com as limitações impostas pela retração do sifão durante o inverno austral e as necessidades fisiológicas excretoras desse composto nitrogenado. Estudos com a arginase renal da $L$. elliptica também revelaram a sua maior resistência à inibição pelos cátions metálicos $\mathrm{Cu}, \mathrm{Zn}, \mathrm{Fe}$ e $\mathrm{Cd}$, quando comparado ao comportamento da arginase de outros bivalves, como por exemplo, Dreissena polymorpha. Assim, a presente revisão reúne informações sobre a história de vida desse bivalve, seu potencial biomarcador e a sua evolução adaptativa nas condições extremas do ambiente marinho Antártico.

Palavras-chave: Antartica, bentos, Laternula elliptica, arginase, metabolismo, ecofisiologia, biomarcadores, metais pesados.

\section{INTRODUCTION}

The adaptation of the Antarctic organisms occurred gradually by a selective pressure caused by the low temperatures, the seasonality of food supply and by a series of geological and climatic events that resulted in the formation of the circumpolar currents and the consequent isolation of the continent (Arntz et al. 2005, Clarke et al. 2005). Though the cooling process of Antarctica began about 35 million years ago, the sea surface temperatures dropped drastically to sub-zero values only in the last 4-5 million years. Therefore, the metabolic adaptation of the Antarctic ectotherms to the extremes of temperature and seasonal food shortage was characterized by the appearance of different molecular structures that have the ability to maintain its energy needs close to freezing (Pörtner 2006, Verde et al. 2006). The appearance of the antifreeze glycoproteins (AFGP), that prevent freezing of body fluids of the Antarctic fishes, about 5 to 14 million years ago, is considered to be the main responsible for the evolutionary success of these organisms (Chen et al. 1997). It has been argued that the polar marine invertebrates do not need additional strategies to withstand the cold, due to the fact that their biological fluids are iso-osmotic to seawater, and rarely go below $-1.9{ }^{\circ} \mathrm{C}$. But recent data indicate that some Antarctic organisms have developed strategies to avoid freeze damage. Eleven benthic invertebrate species have already shown some evidence of their 
cold-tolerance by lowering the freezing point of their biological fluids. But, at present, only the nemertine Antarctonemertes validum appears to have thermal hysteresis proteins (antifreeze proteins), with $1.4^{\circ} \mathrm{C}$ of freezing point depression in its haemolymph (Waller et al. 2006).

So far, studies on the metabolic cold adaptation of the Antarctic ectotherms have focused on the energy metabolism. This is due to its importance for vital functions such as locomotion and reproduction (Clarke 2003). As temperature has a strong effect on the metabolism rates of the ectotherms, many studies were conducted in order to understand the relationship between some aspects of the energy metabolism (oxygen consumption, mitochondrial density, enzyme kinetic parameters under low temperatures, etc) and the ecophysiological behavior of these organisms (Somero 2004, Pörtner 2006).

Though the low temperatures have a marked effect on the adaptation and evolution of the Antarctic organisms, some authors consider that the seasonality of food supply is one of the most important factors that characterize the Antarctic marine ecosystem (Clarke 1988, Eastman 1993, Clarke \& Johnston 1996). Its effects on the Antarctic benthic organisms depend on their trophic position in food web. Herbivores are more strongly affected than carnivores and scavengers (Clarke 1988). This is due to the fact that during winter, with the increase in the ice cover and decrease in daylight period, the primary production in the water column is limited, imposing constraints to the suspension feeders, which may not feed for 2 to 3 months (Barnes \& Clarke 1994, 1995). Studies with the Antarctic holothurian Heterocucumis steineni show that this suspensivore ceases feeding for about four months during the austral winter, reducing its oxygen consumption and protein synthesis, and increasing the excretion of ammonia from a protein based energy metabolism, a strategy adapted for the extreme conditions (Fraser et al. 2004). The effect of food on the metabolic behavior of the Antarctic marine invertebrates was investigated taking into account the energy costs involved with the specific dynamics action of feeding (SDA). Experiments conducted on the limpet Nacella concinna show that about $40-50 \%$ of the energy derived from the ingested food is used for the inherent energy requirements to SDA, which justifies the reduction in the metabolic rates for long non-feeding periods to conserve energy. Measurements of the ratio O:N showed that proteins are used as the sole source of metabolism during the starvation period (Peck \& Veal 2001). In an attempt to understand the effect of temperature and feeding on the metabolic activity of Antarctic benthic organisms, Brockington \& Clarke (2001) compared the metabolism of the sea urchin Sterechinus neumayeri in natural conditions and when deprived of food during summer. They showed that temperature accounts for only 15 to $20 \%$ of the increase in metabolic activity, suggesting that feeding, growth and spawning are the main responsible for the increase of metabolic activity in summer.

On the other hand, the accumulation of heavy metals in tissues of the benthic organisms has been the main target of many baseline studies that intend to establish parameters which can be used in the environmental monitoring programs, particularly in regions close to scientific stations or regions where frequently receive ships (Ahn et al. 1996, Lohan et al. 2001). Elevated cadmium levels in the Antarctic waters have already been reported, and are usually associated with the upwelling of nutrient rich deep water. As cadmium has a high affinity for phosphate, it can be taken up by the phytoplankton, resulting in the accumulation in the tissues of organisms of higher trophic levels through food web (Choi et al. 2003a). In addition, there are naturally elevated levels of copper found in the sediment surface in Maxwell bay, King George Island, derived from the erosion of volcanic rocks by glacier melt-water and introduced in coastal waters by melt-water runoff (Ahn et al. 1996).

Since oysters and mussels are distributed worldwide and often accumulate heavy metals without harm, they have been proposed as bioindicators in monitoring programs under the design of the "Mussel Watch" (Goldberg \& Bertine 2000). Antarctic bivalves such as Laternula elliptica and Adamussium colbecki also seem to satisfy the criteria for this type of program and they may be useful bioindicators for the monitoring of heavy metals in the Antarctic region (Ahn et al. 1996, Ponzano et al. 2001). As these large bivalves are absent in intertidal zones and depths less than $5 \mathrm{~m}$, where the marine environment is more vulnerable to the anthropogenic action, the limpet $N$. concinna has also been included as a biomonitor for those regions (Ahn et al. 2004).

In this context, the bivalve L. elliptica has been 
pointed out as a key species in the Antarctic ecosystem since it plays a key role in pelagic-benthic coupling, transferring energy from the water column to the sediment by biodeposition (Ahn et al. 2003, Momo et al. 2002). Therefore, the present review intends to discuss some aspects of its energy metabolism and its potential use as a biomarker taking into account the extreme conditions of temperature and food supply in the Antarctic environment.

\section{LIFE HISTORY AND ECOPHYSIOLOGY OF Laternula elliptica}

The bivalve Laternula elliptica is endemic to the Antarctic region, and can be found in the shallow waters around the entire Antarctic continent and sub-Antarctic islands including South Shetlands and South Georgia (Dell 1990). Other species of this genus are widely distributed in the tropical and subtropical Indo-Pacific, with only one species in the cold waters of South Australia and Tasmania and none in South Africa, New Zealand and South America (Dell 1972). Laternula elliptica can be found in the shallow sheltered coastal waters (depths $>1 \mathrm{~m}$ ) down to $500 \mathrm{~m}$ depth (Dell 1990, Narchi et al. 2002), but is more common between 15 to $45 \mathrm{~m}$, as in the case of King George Island (Nonato et al. 2000). This bivalve occurs often in dense patches and densities can reach values as much as $80 \mathrm{per}^{2}$ in shallow subtidal regions (Ahn et al. 1996, Ansell \& Harvey 1997, Lohan et al. 2001). The bivalve is a deep-burrowing and largesized species. It generally stays most of the time buried in the sediment. Its extensive siphons allow it to burrow into the sediment over $50 \mathrm{~cm}$ below the sediment surface (Zamorano et al. 1986). This ability in addition to its capacity of moving horizontally over the sediment surface, keeps it safe from the effects of ice scouring and, secondarily, from predators. When it is unburied, the main predators are the starfish Odontaster validus, the nermertine Parbolasia corrugatus, the limpet Neobuccinum eatoni, and some fishes such as Trematomus bernarchii (Zamorano et al. 1986, Kiest 1993).

Laternula elliptica has a relatively long lifespan, up to 36 years, and can attain a length of $12 \mathrm{~cm}$ (Philipp et al. 2005a). The individuals are hermaphrodites and produce lecithotrophic pelagic larva (Pearse et al. 1991). Spawning normally occurs in January and February, but the large interannual variation of productivity in the Antarctic seas strongly affects its gonadal development (Momo et al. 2002, Ahn et al. 2003).

The metabolic demands of L. elliptica can be met by the intake of large quantities of phytoplankton and benthic diatoms during the short Antarctic summer (Ahn et al. 1997) and the use of its energy reserves during the long winterperiod. Its feces create sediments rich in organic material that favors the biodeposition of organic carbon and lithogenic particles, which is an important link for the carbon flux from the water column to the benthos, particularly in phytoplanktonimpoverished coastal waters (Ahn 1993).

Observations in situ of the feeding behavior of this bivalve near the Rothera scientific station, Adelaide Island, showed that it retracts its siphons and stays below the sediment surface during winter (4 months or more), when it ceases feeding, thus reducing its consumption of oxygen by about 3 times compared to summer and mobilizing its energy reserves. Studies on the variation of the O:N (oxygen consumption/individual/hour/excreted ammonia), from September 1998 to August 1999, showed that the energy metabolism of this bivalve is essentially protein- based, with $90 \%$ of the nitrogen derived from the catabolism of amino acids excreted in the form of ammonia and about $10 \%$ as urea (Brockington 2001).

The seasonal variation in temperature and food supply has a strong influence on the tissue mass in marine bivalves, especially in Antarctica. As both factors vary simultaneously in the Antarctic seas, the effect of each one on the development of L. elliptica remains unclear. Ahn et al. (2003) showed that the availability of food may be the main factor governing the growth of the bivalve. In fact, the retraction of the siphons takes place when temperatures and concentration of phytoplankton is low but it is not clear which of these factors is the main responsible for the withdrawn of the siphon below the surface (Brockington 2001).

The seasonality of the metabolism of L. elliptica has been suggested as an important biochemical energy conservation strategy that is responsible for the adaptation of this bivalve to the food restriction imposed by the low productivity of the marine environment for periods of up to 9 months. Comparing to other suspension feeding bivalves from temperate 
waters, L. elliptica has a low consumption of oxygen, which has been interpreted as an energy conservation strategy directed to maximize the energy reserves and biomass during summer, when there is a large food supply. During the winter, when there are feeding constraints, it mobilizes its reserves only for most vital physiological functions (Ahn et al. 1997, Ahn \& Shim 1998). The filtering activity could impose unnecessary energy expenditure during the winter, when primary production is low in the Antarctic seas. Studies on the limpet $N$. concinna shows that the energy spent on specific dynamic action for feeding is around $40-50 \%$ of the total intake (Peck \& Veal 2001). Comparing the seasonal variation of the oxygen consumption of L. elliptica with other benthic ectotherms from temperate and tropical regions, as well as other Antarctic benthic invertebrates, Brockington (2001) concluded that L. elliptica can depress its metabolism during winter, when this bivalve may enter in a dormancy state, retracting its siphons well below the sediment surface.

In general, polar invertebrates have higher lifetime compared to their ecotypes in the temperate and tropical regions (Philipp et al. 2005a). L. elliptica lives longer than the temperate infaunal bivalve, Mya arenaria (maximum life span, 36 and 13 years, respectively). Under low in situ temperatures, oxygen consumption rates of Laternula elliptica are low and two times lower than those of $M$. arenaria, for the same ash free dry mass (AFDM) (Ahn \& Shim 1998, Philipp et al. 2005a). The low oxygen consumption associated to the retraction of the siphons during the austral winter, when it enters in a similar state of dormancy, corroborates to explain its longevity (Brockington 2001).

The longevity of these invertebrates has also been correlated with the generation of free radicals and the corresponding antioxidant defenses, in the context of the basal metabolic rate and the uncoupling of the mitochondrial proton gradient (Ku et al. 1993, Brand, 2000, Philipp et al. 2005a). Comparative studies with L. elliptica and $M$. arenaria have shown that the L. elliptica has high levels of catalase and glutathione as the antioxidant defense systems (Philipp et al. 2005a). Isolated mitochondria of these two bivalves have also shown that the L. elliptica mitochondria function, involved in the respiratory control and uncoupling proton gradient, may result in a constant production of reactive oxygen species (ROS) in relation to the oxygen consumption throughout the lifetime of the animal, which is different from the temperate bivalve, M. arenaria, where this increases with age (Philipp et al. 2005b). These observations corroborate to explain how L. elliptica can live 3 times longer than its ecolike species $M$. arenaria.

\section{BIOMARKER POTENTIAL USE OF Laternula elliptica}

Although anthropogenic contamination of the Antarctic coastal waters is still considered negligible, the increasing need for monitoring human activities and their effects on the Antarctic environment has resulted in a search for a marine organism that can be used a bioindicator for xenobiotics and heavy metals. The circumpolar distribution of L. elliptica, its benthic life style and its capacity to accumulate heavy metals, satisfy the criteria required to implement an environment monitoring program as in the "Mussel Watch". So, this bivalve has been proposed as a useful bioindicator of metal contamination in the Antarctic shallow waters (Ahn et al. 1996, Lohan et al. 2001, Dalla Riva et al. 2004).

Studies conducted on the metal accumulation in benthic organisms near Casey station, Windmill Island, East Antarctica (Duquesne \& Riddle 2002), show that the bivalve Laternula elliptica, the sea urchins Abatus nimrodi and Abatus ingens, the starfish Notasterias armata and the crustacean Paramoera walkeri, have the ability to concentrate heavy metals in their tissues and hence they can be excellent bioindicators of the presence of heavy metals in their environments.

Ahn et al. (1996) have studied the relationship between heavy metal concentrations of marine sediments and their corresponding concentrations in tissues of L. elliptica near Collins Harbor, Maxwell Bay, King George Island. It was found that the kidney of this bivalve accumulates heavy metals, especially $\mathrm{Cd}, \mathrm{Zn}, \mathrm{Pb}, \mathrm{Mn}$ e Ni, compared to other tissues. When compared to the Antarctic scallop Adamussium colbecki, the magnitude of accumulation of some metals in renal tissues of Laternula elliptica were much greater.

Considering the potential use of L. elliptica as 
a bioindicator of heavy metals, Lohan et al. (2001) conducted studies to evaluate the anthropogenic contamination in areas close to the Rothera scientific station, Adelaide Island, Antarctic Peninsula. Their results indicated a possible sediment contamination with copper, either from anthropogenic or from unidentified natural sources near the runways used by aircraft. In this case, the main site of heavy metal bioaccumulation was the renal tissue of L. elliptica.

Studies on the subcellular distribution of copper and cadmium in the tissues of L. elliptica show that the bioaccumulation of these metals occurs mainly in the kidney and in the digestive gland, a major portion of these metals being immobilized in the insoluble fraction of the cell, probably forming electrondense granules which are likely to be metal-rich. In the soluble fraction of tissue cells, these metals are associated with proteins whose molecular weight is similar to those of metallothioneins. Contrary to the renal tissue, the copper present in the digestive gland was probably derived from the food intake or other $\mathrm{Cu}$-enriched particles present in the sediment (Choi et al. 2003a, b).

Marine invertebrates are often subject to seasonal variation of environmental factors such light, food supply and temperature. The range of physiological temperatures in which polar ectotherms can survive is very narrow, which makes the stenotherms very sensitive to variations in temperature. The increase of water temperatures in the range of $0^{\circ} \mathrm{C}$ to $9^{\circ} \mathrm{C}$, can change drastically the biochemical/physiological behavior of $L$. elliptica. When water temperatures raises from $0^{\circ} \mathrm{C}$ to $3^{\circ} \mathrm{C}$, an increase in heartbeat, a reduction in the oxygenation of the haemolimph, and an increase of succinate content in the siphons (indicator of anaerobic metabolism) can be detected. Studies on the metabolic changes in L. elliptica with temperature, identified a critical temperature of $6^{\circ} \mathrm{C}$, when the metabolism changes from aerobic to anaerobic, and a lethal temperature of $9^{\circ} \mathrm{C}$, when $50 \%$ of mortality was observed within a 7 -day period (Peck et al. 2002).

The increase in temperature increases the rate of the mitochondrial respiration and promotes the uncoupling of the proton gradient (Pörtner et al. 1999). As the mitochondrial respiration is the principal source of reactive oxygen species (ROS), the effect of temperature on the mitochondrial capacity of ROS of L. elliptica has been investigated. This bivalve has a low production of ROS by the mitochondria near physiological temperatures in its natural habitat, which doubles when the temperature raises to $7^{\circ} \mathrm{C}$, indicating that this species is very sensitive to thermal stress (Heise et al. 2003). In general, a large number of Antarctic invertebrates are sensitive to variations in temperature and survive only within a narrow thermal window, between 5 to $10{ }^{\circ} \mathrm{C}$ (Pörtner 2006). Though the high Antarctica has not shown signs of warming yet, the Antarctic Peninsula has seen increases in temperatures above $1.5^{\circ} \mathrm{C}$ since the middle of the last century (Vaughan et al. 2003). Hence, it is essential to know the effects of temperature on the metabolism of these organisms to determine the possible effects of global warming on the marine biodiversity of the Antarctic environment.

The formation of superoxide $\left(\mathrm{O}_{2}^{-}\right)$, and hydrogen peroxide $\left(\mathrm{H}_{2} \mathrm{O}_{2}\right)$, in the presence of the transition metallic cations, can give rise to hydroxyl radicals $\left(\mathrm{OH}^{\bullet}\right)$, which are highly reactive and can result in alteration in the lipid, protein and nucleic acid contents (Estevez et al. 2002). The lipid content of L. elliptica is relatively lower than those of bivalves in the temperate waters, and probably does not play any important storage role in the periods where there is food shortage. Although the composition of unsaturated and polysaturated fatty acids are similar to the marine bivalves in warm waters (Ahn et al. 2000), comparative studies of the frozen tissues of L. elliptica and Mya arenaria show that quantity of lipid radicals are higher in the former, which has been related to the iron content in the tissues (Estevez et al. 2002). The presence of transition metals in the animal tissues, particularly iron, have been associated with the formation of hydroxyl radicals, and consequently with the peroxidation of the lipids and damage of the biological membranes (Marks et al. 1996). Then, the capacity for bioaccumulation of these metals in the tissues of L. elliptica could be associated with the formation of free radicals and with its antioxidant defenses (Philipp et al. 2005a).

In summary, the ability of Laternula elliptica in accumulating heavy metals and its metabolic/ physiological response as a function of temperature increases makes this bivalve a potential biomarker and a possible sentinel for monitoring the marine Antarctic environment. 


\section{NITROGEN METABOLISM}

During the winter, L. elliptica shows a reduction in the protein mass more pronounced than the depletion of the lipid and glycogen reserves, indicating that the proteins are being used as an energy source during the periods where there is shortage of food (Ahn et al. 2003). This is also supported by the annual variation in the $\mathrm{O}: \mathrm{N}$ ratio (oxygen consumed/excreted nitrogen) which can vary by a factor of 3 , in winter up to 16 , in summer (Brockington 2001). Values around 3 usually indicate the exclusive use of proteins as the energy substrate, while values between 20 and 25 indicate that protein fuels of $50 \%$ metabolic substrate and above 25 the presence of other energy combustibles (Ikeda \& Hing Fay 1981, Mayzaud \& Conover 1988). The principal events involved in the seasonal metabolism of L. elliptica are shown in Figure 1.

As can be seen from figure 2, the seasonal energetics of L. elliptica is, to some extent, similar to that of other Antarctic benthic organisms, such as the gastropod N. concinna, the holothurian $H$. steineni and the sea urchin $S$. neumayeri. The seasonal metabolic variations in L. elliptica, measured as the oxygen consumption rates (3 times), fall well within the range for other benthic ectotherms of the temperate and tropical regions ( 2 to 4 times), but are higher than those of the Antarctic ectotherms, reinforcing its great ability to depress the metabolism during the austral winter, when siphons are retracted below sediment and these bivalves may enter in a dormancy state (Brockington 2001).

The use of proteins for energetics requires the elimination of aminic nitrogen and the oxidation of the carbon chain of the amino acids. Though $L$. elliptica is a typical ammoniotelic, it excretes about $10 \%$ of nitrogen in the form of urea (Brockington 2001). The probable origin for this may be the hydrolysis of the proteic amino acid L-arginine. The versatility of the this amino acid is shown by its role in physiologically important biochemical processes such as the synthesis of proteins, polyamines, nitric oxide, urea and phosphoarginine (Jenkinson et al. 1996). The principal source of the intracellular L-arginine is the urea cycle in the ureotelic and ureosmotic animals, other than the diet proteins

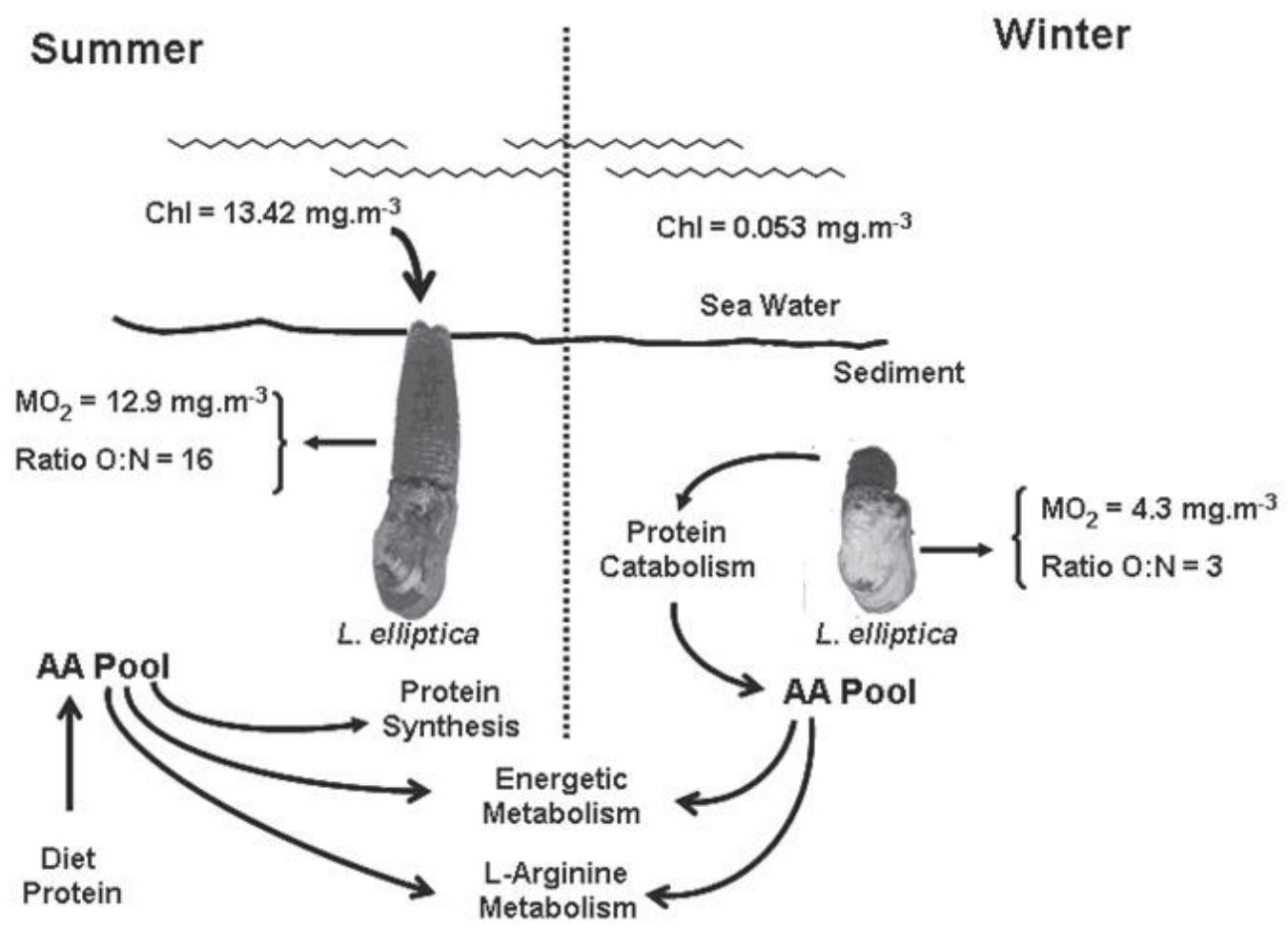

Figure 1. Ecophysiological relationships of the bivalve Laternula elliptica. The great variation in the oxygen consumption $\left(\mathrm{MO}_{2}\right)$ of $\mathrm{L}_{\text {. elliptica between }}$ summer and winter (almost 3 times) has been associated with the specific dynamics action of feeding. The presence of arginase in the renal tissue of this bivalve is considered as an important biochemical strategy for the excretion of the urea during the food shortage period, when siphons retract and the chlorophyll a levels are low (Data from Brockington, 2001). 


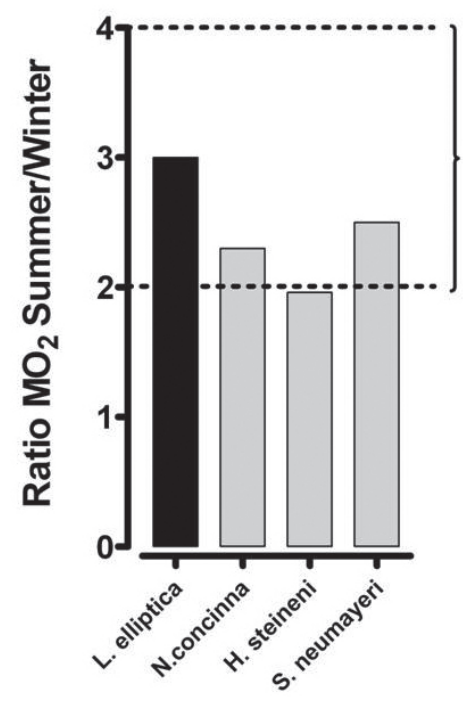

Range for benthic ectotherms

from temperate or tropical

environments

\section{Animals}

Figure 2. Seasonal metabolic changes in some Antarctic ectotherms as a function of the ratio of the oxygen consumed (MO2) in summer to that in winter.

and the catabolism of the intracellular proteins in animals (Figure 3 ).

The presence of arginases in animal tissues is related to the maintenance of the L-arginine levels in the biological fluids, as the maintenance of osmolarity in ureosmotic organisms, and the excretion of urea in ureotelic organisms. Studies of the purified arginases in different animals show that this enzyme has a variety of molecular forms and distinct kinetic properties. The elevated levels of arginase in the penguin liver are related to their protein-rich diet of krill (Rodrigues et al. 1996). In the Antarctic fish, Notothenia neglecta, the argininolitic activity is concentrated mainly on the distal part of the kidney and the liver. As this fish has a low ureogenic capacity, the argininolitic activity must be related to the maintenance of the L-arginine levels in the tissues (Rodrigues et al. 2006).

The distribution of arginases in the tissue of marine mollusks does not follow a standard pattern. High levels of this enzyme were found in the gills of marine mollusks such as the gastropod Concholepas concholepas and the bivalve Semele solida (Carvajal et al. 1984, Carvajal et al. 1994), whereas, in others, such as the marine polyplacophoran Chiton latus, the argininolitic activity is concentrated in the gills and the muscular foot (Carvajal et al. 1988).

Studies on the isolated tissues of the L. elliptica (digestive gland, kidney, siphons, gonads and gills) show that the argininolitic activity is concentrated

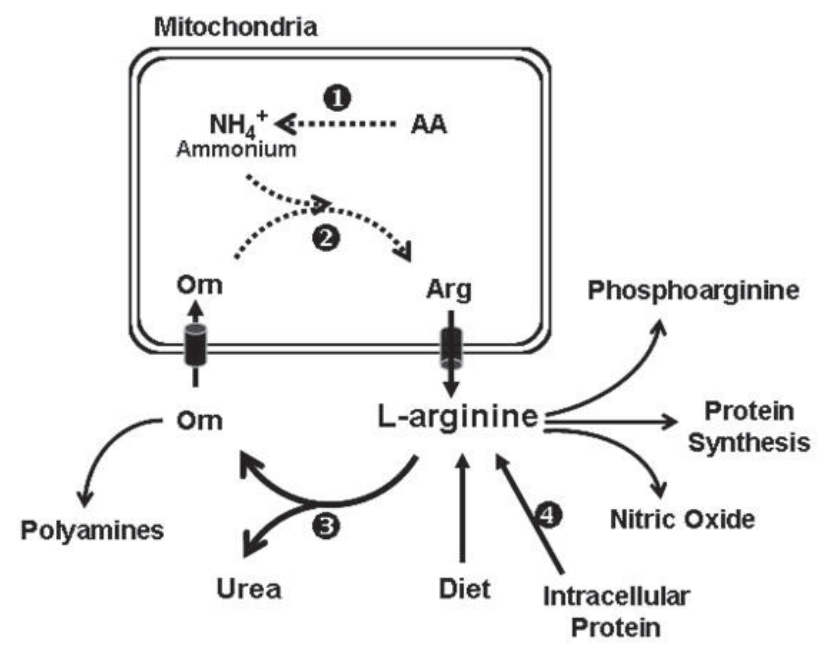

Figure 3. Metabolism of the L-arginine amino acid. The liberation of ammonia from the catabolism of amino acids (AA) (1), is generally fixed in the urea cycle (2) of ureotelic and ureosmotic animals. Arginases (3) are the enzymes that catalyze and hydrolyze the L-arginine, and take part in the urea cycle as a terminal enzyme, maintaining the tissue levels of the amino acid. In the case of Laternula elliptica, the protein catabolism (4) used for energetics purpose may fuel the L-arginine pool in the biological fluids of the bivalve.

in the renal tissue, whereas that activity is just close to the limit of detection method in other tissues (Rodrigues et al. in prep). In this case, the presence of arginase only in the renal tissue may be related to the seasonal metabolism of L. elliptica and its inherent needs to maintain the tissue L-arginine levels, as in the energy metabolism based on proteins. The presence of arginase in the kidneys of this bivalve can make possible the excretion of urea during winter, when the apparent retraction 


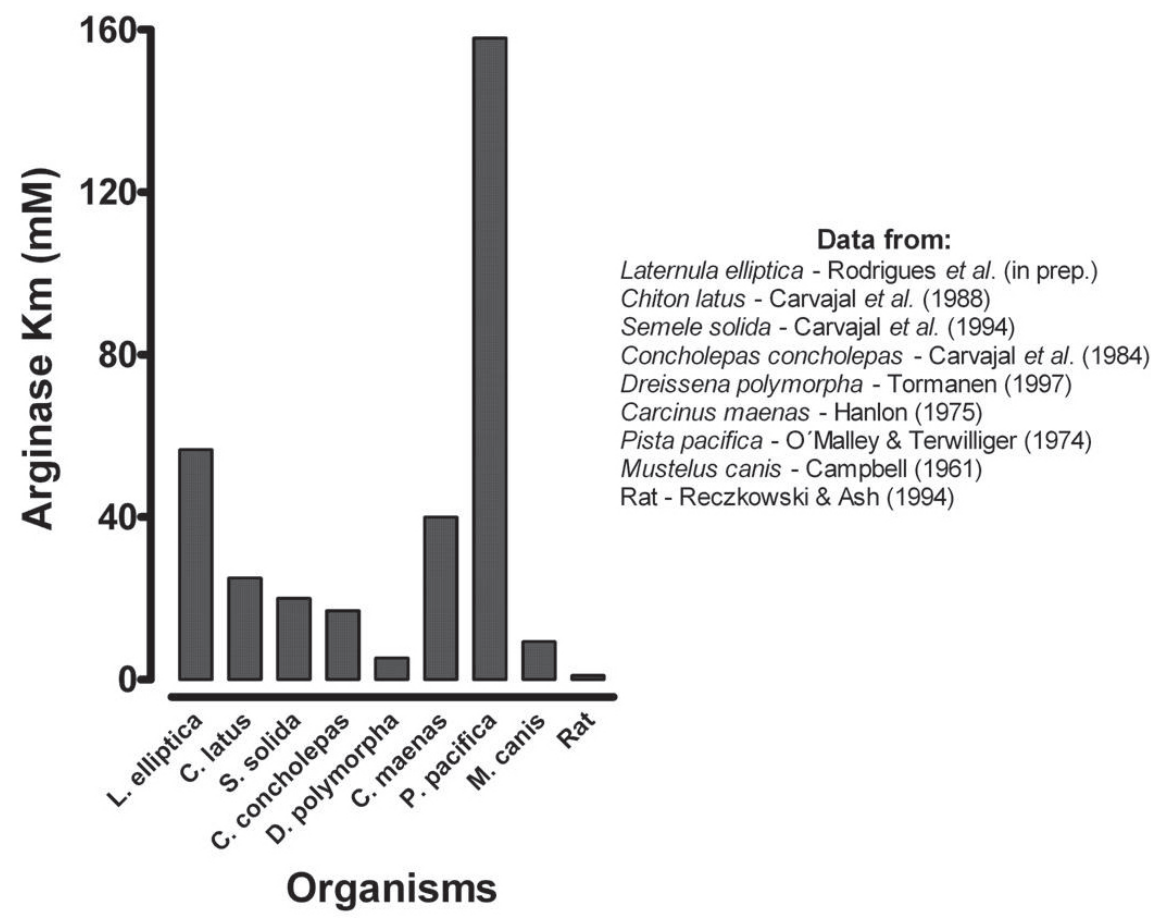

Figure 4. Km values of arginase extracted from the tissues of vertebrates and invertebrates.

of the siphon below the sediment compromises the filtering process. In this case, the hydrolysis of the amino acid L-arginine in the renal tissue could represent an important metabolic strategy to make possible the excretion of urea when the metabolic activity of the bivalve is reduced. In literature, as the tissue levels of arginase were determined in different conditions of $\mathrm{pH}$, temperature, manganese and L-arginine concentrations, comparisons between the argininolitic levels from mollusks of the temperate environments and L. elliptica are quite difficult.

Michaelis constant $(\mathrm{Km})$ for the L. elliptica renal arginase was estimated as $56.6 \pm 5.7 \mathrm{mM}$ (Santos et al. 2005). This is approximately double that of the marine mollusks from temperate waters and about 10 times higher than that of the freshwater mussel Dreissena polymorpha (Carvajal et al. 1984, Carvajal et al. 1994, Tormanen 1997). The Km values for the ureotelic animals (ex. rodents), and ureosmotics (ex: elasmobranchii) are normally lower than those of the uricotelic and ammoniotelic animals (Figure 4) (Jenkinson et al. 1996).

The arginases are metalloenzymes dependent on the divalent cation for complete activity. The probable cation for this enzyme is $\mathrm{Mn}^{2+}$, but cobalt and nickel have also been reported as activators for some arginases (Jenkinson et al. 1996). Studies conducted on the renal arginase of L. elliptica show that the activating effect of $\mathrm{Mn}^{2+}$ is very discrete as well as the inhibitory effect of $\mathrm{Cu}^{2+}, \mathrm{Fe}^{3+}, \mathrm{Zn}^{2+} \mathrm{e}$ $\mathrm{Cd}^{2+}$ (Rodrigues et al. in prep.), compared to those effects on the arginase activity in zebra mussel ( $D$. polymorpha) (Figure 5).

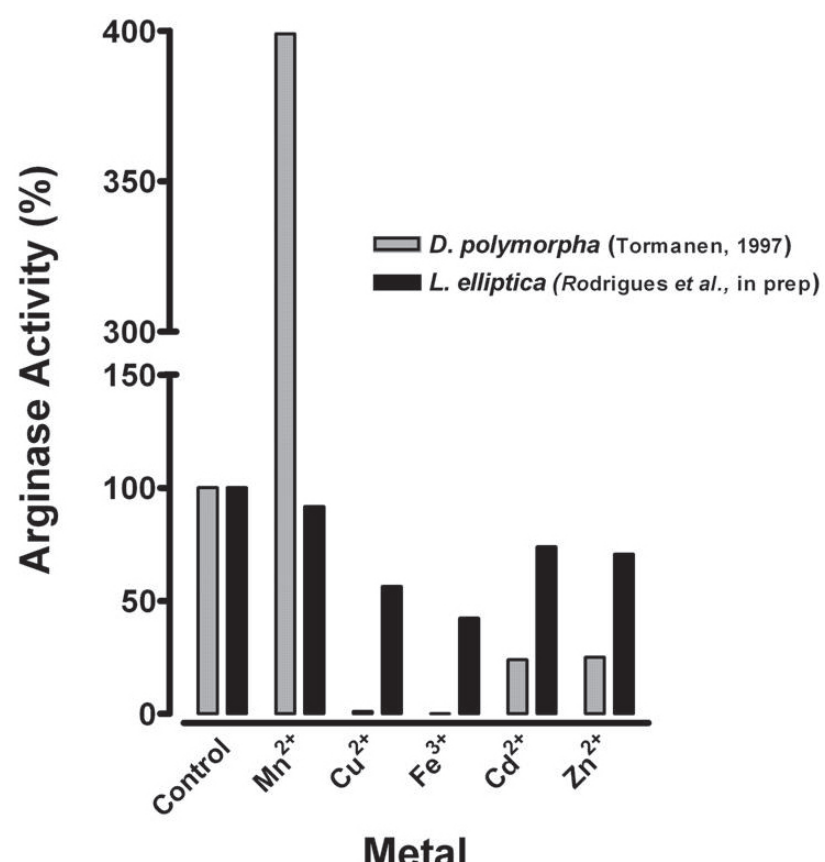

Figure 5. Relative activity of Laternula elliptica and Dreissena polymorpha arginases in the presence of some physiological and non-physiological metallic cations. The value of $100 \%$ is the control activity determined without the addition of any metal to the reaction system. 
The effect of heavy metals on the arginase activity in one species may differ from another. In the gastropod $C$. concholepas and the bivalve D. polymorpha, $\mathrm{Mn}^{2+}, \mathrm{Ni}^{2+}$ e $\mathrm{Co}^{2+}$ act satisfactorily as co-factor activators in the reactions catalyzed by arginase, whereas $\mathrm{Zn}^{2+} \mathrm{e} \mathrm{Cd}^{2+}$ strong inhibit $C$. concholepas and $\mathrm{Fe}^{3+}$ and $\mathrm{Cu}^{2+}$, in concentrations of $1 \mathrm{mM}$, inhibit almost $100 \%$ of the argininolitic activity of the Zebra mussel (Carvajal et al. 1984; Tormanen 1997). In contrast to these mollusks, the arginase activity of L. elliptica is inhibited by only $26 \%, 30 \%, 44 \%$ and $58 \%$ by $\mathrm{Cd}^{2+}, \mathrm{Zn}^{2+}, \mathrm{Cu}^{2+}$ and $\mathrm{Fe}^{3+}$, respectively. Considering that the levels of copper in the sediments of some Antarctic coastal regions (> $\left.80 \mathrm{mg} \cdot \mathrm{Kg}^{-1}\right)$ is comparable to some polluted regions worldwide and the ability of Laternula elliptica in accumulating $\mathrm{Cd}$ and $\mathrm{Zn}$ (200 and 20 times, respectively) (Ahn et al. 1996), the presence of a different form of arginase in the L. elliptica kidney, more resistant to heavy metal inhibition, can be considered as an adaptative advantage. But the metabolic tolerance of these organisms to the high levels of heavy metals present in the sediments or water column is still a matter of question.

Studies about the metals concentration in the sediments around McMurdo (USA) station and its bioaccumulation in the tissues of L. elliptica, suggest that the total metal concentrations in the bivalve tissues may not be an apropriate method to detect contamination from anthropogenic sources (Negri et al. 2006), and then it is necessary to study the biodeposition of these metals in the sediments. Therefore, information about the subcellular distribution of these metals and their true concentrations (in the form of free metal ions) in the L. elliptica tissues, can contribute to a better understanding of its ecophysiological relationships and identification of new parameters as heavy metals biomarkers. The formation of electron dense granules, the metallothionein chelant effect (Choi et al. 2003a, b) and the presence of the arginases resistant to inhibition by heavy metals, particularly $\mathrm{Cd}, \mathrm{Cu}, \mathrm{Zn}$ and $\mathrm{Fe}$ could be important mechanisms involved in the L. elliptica ecophysiology.

In conclusion, the adaptation of this infaunal bivalve to the extreme conditions of temperature, food shortage, naturally high levels of metals and ice scouring on Antarctic inshore, resulted in a set of biochemical and physiological strategies to maintain life overwintering, where the reduction in the metabolic rates, the siphon retraction, the presence of enzymes resistant to the heavy metal inhibition and the protein use for energetics, are of fundamental importance for the successful L. elliptica adaptation to Antarctic environment.

\section{REFERENCES}

AHN, I.-Y. 1993. Enhanced particle flux through the biodeposition by the Antarctic suspension-feeding bivalve Laternula elliptica in Marian Cove, King George Island. Journal of Experimental Marine Biology and Ecology, 171: 75-90.

AHN, I.-Y.; CHO, K.W.; CHOI, K.-S.; SEO, Y. \& SHIN, J. 2000. Lipid content and composition of the Antarctic lamellibranch, Laternula elliptica (King \& Broderip) (Anomalodesmata: Laternulidae), in King George Island during an austral summer. Polar Biology, 23: 24-33.

AHN, I.-Y.; CHUNG, K.H. \& CHOI, H.J. 2004. Influence of glacial runoff on baseline metal accumulation in the Antarctic limpet Nacella concinna from King George Island. Marine Pollution Bulletin, 49: 119-141.

AHN, I.-Y.; CHUNG, H.; KANG, J.S. \& KANG, S.H. 1997. Diatom composition and biomass variability in near shore waters of Maxwell Bay, Antarctica, during the 1992/1993 austral summer. Polar Biology, 17: 123-130.

AHN, I.-Y.; LEE, S.H.; KIM, K.T.; SHIM, J.H. \& KIM, D.-Y. 1996. Baseline heavy metal concentrations in the Antarctic clam, Laternula elliptica in Maxwell bay, King George Island, Antarctica. Marine Pollution Bulletin, 32(8/9): 592-598.

AHN, I.-Y. \& SHIM, J. H. 1998. Summer metabolism of the Antarctic clam, Laternula elliptica (King and Broderip) in Maxwell Bay, King George Island and its implications. Journal of Experimental Marine Biology and Ecology, 224: 253-264.

AHN, I.-Y.; SURH, J.; PARK, Y.-G.; KWON, H.; CHOI, K.-S.; KANG, S.-H.K.; CHOI, K.-W. \& CHUNG, H. 2003. Growth and seasonal energetics of the Antarctic bivalve Laternula elliptica from King George Island, Antarctica. Marine Ecology Progress Series, 257: 99-110.

ANSELL, A. D. \& HARVEY, R. 1997. Protected larval development in the Antarctic bivalve Laternula elliptica (King and Broderip) (Anomalodesmata: Laternulidae). Journal of Molluscan Studies, 63: 285-286.

ARNTZ, W.E.; THATJE, S.; GERDES, D.; GILI, J-M.; GUTT, J.; JACOB, U.; MONTIEL, A.; OREJAS, C. \& TEIXIDÓ, 
N. 2005. The Antarctic-Magellan connection: macrobenthos ecology on the shelf and upper slope, a progress report. Scientia Marina, 69(2): 237-269.

BARNES, D.K.A. \& CLARKE, A. 1994. Seasonal variation in the feeding activity of four species of Antarctic bryozoan in relation to environmental factors. Journal of Experimental Marine Biology and Ecology, 181(1): 117-133.

BARNES, D.K.A. \& CLARKE, A. 1995. Seasonality of feeding activity in Antarctic suspension feeders. Polar Biology, 15(5): 335-340.

BRAND, M.D. 2000. Uncoupling to survive? The role of mitochondrial inefficiency in ageing. Experimental Gerontology, 35(6/7): 811-820.

BROCKINGTON, S. 2001. The seasonal energetics of the Antarctic bivalve Laternula elliptica (King and Broderip) at Rothera Point, Adelaide Island. Polar Biology, 24: 523530 .

BROCKINGTON, S. \& CLARKE, A. 2001. The relative influence of temperature and food on the metabolism of a marine invertebrate. Journal of Experimental Marine Biology and Ecology, 258: 87-99.

CARVAJAL, N.; BUSTAMANTE, M.; HINRICHSEN, P. \& TORRES, A. 1984. Properties of arginase from the sea mollusk Concholepas concholepas. Comparative Biochemistry and Physiology, 78B(3): 591-594.

CARVAJAL, N.; KESSI, E.; BIDART, J. \& ROJAS, A. 1988. Properties of arginase from the foot muscle of Chiton latus. Comparative Biochemistry and Physiology, 94B(2): 385-388

CARVAJAL, N.; URIBE, E. \& TORRES, C. 1994. Sub cellular localization, metal ion requirement and kinetic properties of arginase from the gill tissue of the bivalve Semele solida. Comparative Biochemistry and Physiology, 109B(4): 683-689.

CHEN, L.; DEVRIES, A.L. \& CHENG, C.H. 1997. Evolution of antifreeze glycoprotein gene from a trypsinogen gene in Antarctic notothenioid fish. Proccedings of the National Academy of Science of the United States of America, 94(8): 3811-3816.

CHOI, H.J.; AHN, I.-Y.; KIM, K.-W.; KIM, H.-A. \& LEE, I.-S. 2003a. Sub cellular distribution of naturally cadmium in the Antarctic clam Laternula elliptica. Bulletin Environmental Contamination and Toxicology, 71: 83-89.

CHOI, H.J.; AHN, I.-Y.; KIM, K.-W.; LEE, I.-S.; LEE, I.-S. \& JEONG, K.-H. 2003b. Sub cellular accumulation of $\mathrm{Cu}$ in the Antarctic bivalve Laternula elliptica from a naturally Cu-elevated bay of King George Island. Polar Biology, 26: 601-609.
CLARKE, A. 1988. Seasonality in the Antarctic marine environment. Comparative Biochemistry and Physiology Part B: Biochemistry and Molecular Biology, 90(3): 461-473.

CLARKE, A. 2003. Costs and consequences of evolutionary temperature adaptation. Trends in Ecology \& Evolution, 18(11): 573-581.

CLARKE, A. \& JOHNSTON, I.A. 1996. Evolution and adaptive radiation of Antarctic fishes. Trends in Ecology \& Evolution, 11(5): 212-218

CLARKE, A.; BARNES, D.K.A. \& HODGSON, D.A. 2005. How isolated is Antarctica? Trends in Ecology and Evolution, 20(1): 1-3.

DALLA RIVA, S.; ABELMOSCHI, M.L.; MAGI, E. \& SOGGIA, F. 2004. The utilization of the Antarctic environmental specimen bank (BCAA) in monitoring $\mathrm{Cd}$ and $\mathrm{Hg}$ in an Antarctic coastal area in Terra Nova Bay (Ross sea - Northern Victoria Land). Chemosphere, 56: 59-69.

DELL, R.K. 1972. Antarctic Benthos. Advances in Marine Biology, 10: 1-216.

DELL, R.K. 1990. Antarctic Mollusca with special reference to the fauna of Ross Sea. Bulletin of Royal Society of New Zealand, 27: 1-311.

DUQUESNE, S. \& RIDDLE, M.J. 2002. Biological monitoring of heavy-metal contamination in coastal waters off Casey Station, Windmill Islands, East Antarctica. Polar Biology, 25: 206-215.

EASTMAN, J.T. 1993. Antarctic Fish Biology: Evolution in a Unique Environment, Academic Press, San Diego and New York.

ESTEVEZ, M.S.; ABELE, D. \& PUNTARULO, S. 2002. Lipid radical generation in polar (Laternula elliptica) and temperate (Mya arenaria) bivalves. Comparative Biochemical Physiology, 132B: 729-737.

FRASER, K.P.P.; PECK, L.S. \& CLARKE, K. 2004. Protein Synthesis, RNA Concentrations, Nitrogen Excretion, and Metabolism Vary Seasonally in the Antarctic Holothurian Heterocucumis steineni (Ludwig 1898). Physiological and Biochemical Zoology, 77: 556-569.

GOLDBERG, E.D. \& BERTINE, K.K. 2000. Beyond the Mussel Watch - new directions for monitoring marine pollution. The Science of The Total Environment, 247(2/3): 165-174.

HEISE, L.; PUNTARULO, S.; PÖRTNER, H.O. \& ABELE, D. 2003. Production of reactive oxygen species by isolated mitochondria of the Antarctic bivalve Laternula elliptica (King and Broderip) under heat stress. Comparative Biochemical and Physiology, 134C: 79-90.

IKEDA, T. \& HING FAY, E. 1981. Metabolic activity of 
zooplankton from the Antarctic Ocean. Australian. Journal of Marine and Freshwater Research, 32: 921-930.

JENKINSON, C.P.; GRODY, W.W. \& CEDERBAUM, S.D. 1996. Comparative properties of arginases. Comparative Biochemistry and Physiology, 114B(1): 107-132.

KIEST, K.A. 1993. A relationship of diet to prey abundance and the foraging behavior of Trematomus bernacchii. Polar Biology, 13(5): 291-296.

KU, H.-H.; BRUNK, U.T. \& SOHAL, R.S. 1993. Relationship between mitochondrial super oxide and hydrogen peroxide production and longevity of mammalian species. Free Radical Biology and Medicine, 15(6): 621-627.

LOHAN, M.C.; STATHAM, P.J. \& PECK, L. 2001. Trace metals in the Antarctic soft-shelled clam Laternula elliptica: implications for metal pollution from Antarctic research stations. Polar Biology, 24: 808-817.

MARKS, D.B.; MARKS, A.D. \& SMITH, C.M. 1996. Basic medical biochemistry - A clinical approach. Wiliams \& Wilkins, Baltimore, Maryland.

MAYZAUD, P. \& CONOVER, R.J. 1988. Review: O:N atomic ratio as a tool to describe zooplankton metabolism. Marine Ecology Progress Series, 45: 289-302.

MOMO, F.; KOWALKE, J.; SCHLOSS, I.; MERCURI, G. \& FERREYRA, G. 2002. The role of Laternula elliptica in the energy budget of Potter Cove (King George Island, Antarctica). Ecological Modelling, 155: 43-51.

NARCHI, W.; DOMANESCHI, O. \& PASSOS, F.D. 2002. Bivalves antárticos e subantárticos coletados durante as expedições científicas brasileiras à Antártica I a IX (1982 - 1991). Revista Brasileira de Zoologia, 19 (3): 645-675.

NEGRI, A.; BURNS, K.; BOYLE, S.; BRINKMAN, D. \& WEBSTER, N. 2006. Contamination in sediments, bivalves and sponges of McMurdo Sound, Antarctica. Environmental Pollution, 143: 456-467.

NONATO, E.F.; BRITO, T.A.S.; PAIVA, P.C.; PETTI, M.A.V. \& CORBISIER, T. 2000. Benthic megafauna of the nearshore zone of Martel Inlet (King George Island, South Shetland Islands, Antarctica): depth zonation and underwater observations. Polar Biology, 23: 580-588.

PEARSE, J.S.; McCLINTOCK, J.B. \& BOSCH, I. 1991. Reproduction of Antarctic benthic marine invertebrates: tempos, modes and timing. American Zoologist, 31: 65-80.

PECK, L.S.; PÖRTNER, H.O. \& HARDEWIG, I. 2002. Metabolic demand, oxygen supply, and critical temperatures in the Antarctic bivalve Laternula elliptica. Physiological and Biochemical Zoology, 75(2): 123-133.

PECK, L.S. \& VEAL, R. 2001. Feeding, metabolism and growth in the Antarctic limpet, Nacella concinna (Strebel 1908). Marine Biology, 138: 553-560.

PHILIPP, E.; BREY, T.; PÖRTNER, H.-O. \& ABELE, D. 2005a. Chronological and physiological ageing in a polar and a temperate mud clam. Mechanisms of Ageing and Development, 126: 598-609.

PHILIPP, E.; PÖRTNER, H.-O. \& ABELE, D. 2005b. Mitochondrial ageing of a polar and a temperate mud clam. Mechanisms of Ageing and Development, 126(5): 610-619.

PONZANO, E.; DONDERO, F.; BOUQUEGNEAN. K.-M.; SACK, R.; HUNZIKER, P. \& VIARENGO, A. 2001. Purification and biochemical characterization of a cadmium metallothionein from the digestive gland of the Antarctic scallop Adamussium colbecki (Smith, 1902). Polar Biology, 24: $147-153$

PÖRTNER, H.O. 2006. Climate - dependent evolution of Antarctic ectotherms: an integrative analysis. Deep-sea Research II, 53: 1071-1104.

PÖRTNER, H.O.; HARDEWING, I. \& PECK, L.S. 1999. Mitochondrial function and critical temperature in the Antarctic bivalve, Laternula elliptica. Comparative Biochemistry and Physiology, 124A: 179-189.

RODRIGUES, E.; RIBEIRO, A.C.M.T. \& BACILA, M. 2006. L-arginine metabolism in mitochondria isolated from the liver of Antarctic fish Notothenia rossii and Notothenia neglecta. Brazilian Archives of Biology and Technology, 49(5): 825833.

RODRIGUES, E.; ROSA, R. \& BACILA, M. 1996. Comparative aspects of the nitrogen metabolism in Antarctic birds. Trends in Comparative Biochemistry \& Physiology, 2: 47-63.

SANTOS, M.R.S.; VANI, G.S. \& LAVRADO, R. 2005. Effects of heavy metals and fluoride on arginase activity of Antarctic clam, Laternula elliptica. In: IX SCAR International Biology Symposium: Evolution and Biodiversity in Antarctica, UFPR, Curitiba, PR. Abstracts, p 224.

SOMERO, G. N. 2004. Adaptation of enzymes to temperature: searching for basic "strategies". Comparative Biochemistry and Physiology, 139B: 321-333.

TORMANEN, C.D. 1997. The effect of metal ions on arginase from the zebra mussel Dreissena polymorpha. Journal of Inorganic Biochemistry, 66: 111-118.

VAUGHAN, D.G.; MARSHALL,G.J; CONNOLLEY, W.M.; PARKINSON, C.; MULVANEY, R.; HODGSON, D.A.; KING, J.C.; PUDSEY, C.J. \& TURNER, J. 2003. Recent rapid regional climate warming on the Antarctic Peninsula. Climatic change, 60: 243-274.

VERDE, C.; PARISI, E. \& DI PRISCO, G. 2006. The evolution of thermal adaptation in polar fish. Gene, 385: 137-145. 
WALLER, C.L.; WORLAND, M.R.; CONVEY, P. \& BARNES, D.K.A. 2006. Ecophysiological strategies of Antarctic interstitial invertebrates faced with freezing stress. Polar Biology, 29: 1077-1083.

ZAMORANO, J.H.; DUARTE, W.E. \& MORENO, C.A. 1986. Predation upon Laternula elliptica (Bivalvia, Anatinidae): a field manipulation in South Bay, Antarctica. Polar Biology, 6: 139-143.

Submetido em 20/08/2007. Aceito em 12/09/2007. 